\title{
Reflexions on Urban Gardening in Germany
}

\author{
Evelyn Gustedt \\ Academy for Spatial Research and Planning, Leibniz Forum for Spatial Sciences, Hannover, Germany. \\ E-Mail: Gustedt@ARL-net.de, Tel.: +49 5113484229
}

Submitted: 8 February 2016 | In revised form: 20 October 2016 | Accepted: 17 January 2017 | Published: 17 July 2017

\begin{abstract}
This article reflects on traditional and contemporary gardening movements in Germany. The focus is on forms of gardening, that take place in spaces subject to land lease agreements and similar forms of tenancy or of illegal land take or squatting. The author examines various definitions taking into account the variety of practices, the development of urban gardening over time, and the respective backgrounds or values that users relate to such gardening activities. The examination of definitions led to the drawing up of a timeline of traditional and contemporary gardening movements in Germany and to the tentative approaching of this issue from a semantic perspective. The latter is due to the usage of many different terms mostly as yet undefined in a legal sense. Translation into English or, most likely, to any other language, further blurs the common understanding of the terms used. The author concludes with some considerations on these gardening movements in relation to urban sustainable developments. A presentation at the $5^{\text {th }}$ Rencontres Internationals de Reims on Sustainability Studies, dedicated to Urban Agriculture - Fostering the Urban-Rural Continuum, which took place in October 2015 in Reims/France was the starting point of this article. The basis of this article is a literature review, nourished to a certain extent by observations randomly made over many years and complemented through talks with competent young colleagues. Special thanks go to Martin Sondermann, Leibniz University Hannover, who shared his research experience in various discussions with the author, as well as to Friederike Stelter, internship student at the author's place of work, who gave highly appreciated support to the preparation of the presentation.
\end{abstract}

Keywords: allotment gardens; urban gardening; contemporary gardening movements; urban agriculture

\section{Introduction}

If one starts to think about urban gardening, a whole range of terms appears to characterize gardening activities that take place in inner-urban spaces or at the fringe of settlement areas. As with most human activities, these are also an expression of individuals' needs and behaviours. The needs may be basic ones or desired luxury. They will have repercussions on our ways of living. The behaviours are in accordance with where the individuals concerned were raised (social stratum, nation, individual socialization), their values, and their language. Overall, these factors lead to different understandings of gardening and of how and where it takes place. Whatever gardening activities exist in the spaces mentioned above, they have a direct impact on urban spatial patterns.

The manifold uses of private gardens directly attached to private houses also represent a form of urban gardening in the mere sense that the activities happen in urban areas, without, however, claiming any societal or public function in general. Nevertheless, they contribute to the green infrastructure and natural patterns of ur- 
ban areas. In contrast, gardening activities in Germany based on land-lease agreements and other similar forms of tenancy are very often related to societal visions and the wish and willingness of parts of society to care for a better world. The very titles of relevant websites give some indication of this tendency: Urban Gardening-Mit Gärten die Welt verändern (Urban Gardening-Change the World with Gardens; author's translation) [1]. In the focus of the current reflexions are new forms of gardens, as well as traditional gardens known as allotment gardens (Kleingärten or Schrebergärten) in Germany.

\section{About Definitions}

The broad variety of terms used in (peer reviewed) articles by professionals (landscape architects, planners, geographers, sociologists, etc.), popular scientific books and guidelines, websites of specific social groups, associations of allotment gardens or newspaper articles shows that there is still a great deal of ambiguity concerning the categorization of these different forms of gardening. Due to varying points of interest-who is writing why about what-a clear differentiation is not possible. However, this would be relevant, or at least helpful, for a common discussion-especially a crossborder discussion-and, from a planner's point of view, for approaching the management of urban development processes with regard to citizens' gardening activities that are presumably bound to foster the sustainability of the city. For researchers, clarification could lead to a better understanding of ongoing activities, their contribution to a number of social issues of urban development and their possible transferability in the sense of making use of 'lessons learned'. This article does not go as far as to resolve the ambiguity of terms but reflects on some approaches to narrow the subject matter.

While some authors concentrate on the scale of the spaces in question, others look at their social or sustainable value for the urban fabric. Thus, the focus for some is on nourishing the world, and others try to introduce structure into an unstructured discussion. A good example in this regard are the deliberations of Berges et al. [2] who developed a typology of urban agriculture based on the levels of retail of the products, the interests of actors involved in the production, and the type of actors. The retail levels considered are micro, meso, and macro-connected on one hand to subsistence, socio-cultural and commercial interests, and on the other hand to individuals/private households, associations and start-ups, and enterprises. This three-dimensional categorization leads to ideal types, subtypes, and mixed types of urban agriculture (See Figure 1).

Berges et al. use the term urbane Landwirtschaft in their German publication, which translates as urban agriculture and/or farming. They thus describe a way of using inner-urban land to produce fruits, veg- etables, herbs, and animal products (eggs, milk, and meat). This blurs the semantic border between terms (urban agriculture $<>$ urban gardening). The term urban agriculture or urban farming seems acceptable for what they call the ideal type of macro-level related, commercial interests-driven enterprises. The term agriculture connotes-at least in the author's perception of the German language-the more or less industrialized, professional (on the basis of specific knowledge \& professional education) production of nutrition of different kinds with the objective of earning one's living and supporting a family and/or further collaborators, and to respond to the market's or consumers' needs. This entails the use of contiguous spaces of certain dimensions that are not available in urban, densely settled areas, and also integration into a worldwide market, or at least dependency on this market and its influencing powers-mainly with regard to the prices of products and production conditions.

On the other hand, for the other ideal types depicted by Berges et al. (the subsistence type: micro level, individual or private household driven; the socio-cultural type: meso level, associations or start-ups driven) the term urban gardening seems appropriate. These forms of activities experience, at least to a certain extent, the same influences as urban agriculture or farming, increasingly so as they grow and become commercial, in a first instance most likely via barter trade or direct marketing. The semantic connotation perceived by the author stems also from the traditional differentiation between two professional and scientific disciplines in Germany: Gartenbau and the abovementioned Landwirtschaft. Here, Gartenbau (translated as horticulture or gardening) is more likely to permeate the urban fabric than agriculture (Landwirtschaft) due to the smaller areas needed. The author would go even further in claiming that the terms (agriculture $>$ horticulture $>$ gardening) reflect a decreasing demand in terms of the dimensions of spaces required.

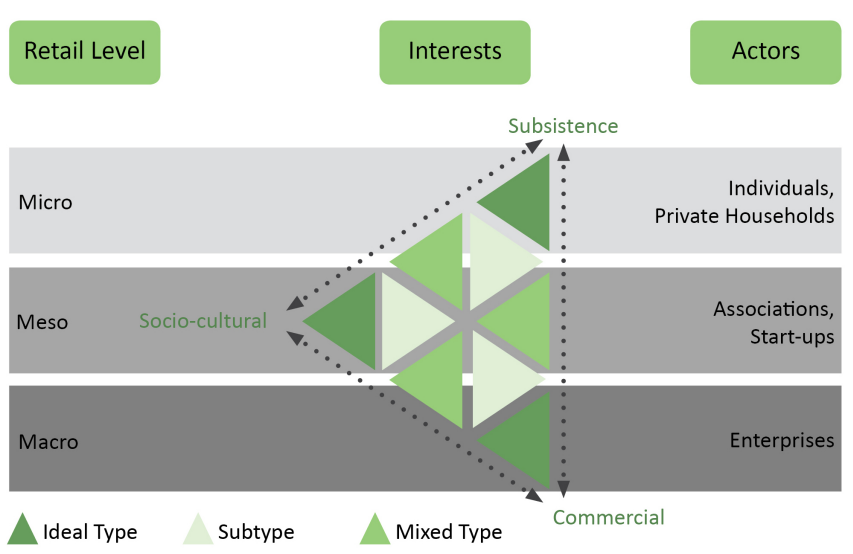

Figure 1. Typology of Urban Agriculture ([2], p. 12; Slightly changed and translated into English. 
Karge [3] explains how understandings of the respective terms, at least in the German language, can be traced back semantically and to what extent these semantic developments provoked the dichotomy of 'the' Urban and 'the' Rural. Pointing out that the terms Landwirtschaft and Agrarwirtschaft describe the same activities, Karge [3] sees the former as defining, in contrast to the latter, the place where the activity is executed: in a rural area (auf dem Lande). Karge [3] goes on to explain the background of the antagonism between urban and rural, inducing the emergence of a different appreciation of urban or rural living and of urban or rural inhabitants. He finally reveals, quoting Sassen/Dotan and their concept of In-BetweenSpace [4], that urban gardens-and Karge does not use the term agriculture in this argument (!)—could be a good starting point to resolve exactly that dichotomy. Urgently needed solutions for the global challenges of the production of healthy nutrition on the one hand, and the reduction of the still increasing waste of natural resources, on the other hand, could be incubated in the complexity of the urban fabric with its highly innovative potential [5]. This could lead to the planting of another world-a very ambitious and challenging objective!

Rosol's PhD [6] concentrates on community gardens and describes them as a new type of open space. The main characteristic of community gardens is the still unusual manner of production and operation methods: shared and voluntary maintenance, open to the public. She differentiates between three types of community gardens: neighbourhood gardens, thematic gardens, and thematic neighbourhood gardens. The latter combine both characteristics: addressing the immediate proximity and concentrating on a certain thematic focus or a target group. With respect to the emergence and management of such gardens, Rosol [6] detected a broad variety of self-organization, support, and constitutive motivations. She explains their emergence with massive economic changes (Post-Fordism) leading to decreasing budgets in open and green spaces' administrations and, as a consequence, to a qualitative decrease in green spaces. These changes go along with new forms of local governance and, at the same time, with a higher appreciation of civil engagement [6]. Not surprisingly, Rosol [6] detects various positive as well as negative impacts of such gardens on both active individuals and the public. From her viewpoint, the community gardens deliver a functional and qualitative amendment to other arrangements of green areas (public green spaces, private gardens, etc.) without substituting them. Astonishingly, from a perspective of open space planning, she judges them to represent a positive alternative to both private and allotment gardens.

Nonetheless, later in her conclusions she calls for an increased support for these gardens through the expert backing of the public sector, paid jobs and better contracts implying time scales for their existence. At the same time, Rosol makes clear that community gardens do not provide financial relief for communities and they should not expect it either. One has to question whether, in times of budgetary difficulties in most communities, more support for community gardens would mean less support for their traditional sister: the allotment garden. Sondermann/Steffenhagen [7] describe urban gardens as an extension of traditional allotment gardens, stating that they cannot be traced back to this traditional form but are rather linked to the community garden movement in New York City that started in the nineteen seventies. Nevertheless, both have the same social orientation, aiming to provide leisure and nutrition. Furthermore, in their contribution to the recently published book on "Urban Allotment Gardens in Europe", Ioannou, Morán, Sondermann et al. [8] prove: "Many of these (forms of gardening) such as collective, community guerilla, intercultural or neighborhood gardens are quite similar in their affiliation to local and global movements or intellectual traditions like sustainability, green cities, solidarity and social cohesion or more natural ways of inhabiting urban space".

It is not yet clear what kind of various connotations go along with this variety of terms. We can read not only about urban gardens but also about allotments, community gardens, neighbourhood gardens, balcony or roof gardens, and gardening activities such as guerrilla, social, intercultural, thematic, etc. Most definitions, both those addressing placesgardens - and those describing activities - gardening - do not have a legal definition in Germany, except allotment gardens. Hence, for now, the author subordinates all these manifestations of gardens and gardening activities under the more general term of urban gardens/gardening. In doing so, the author intentionally does not follow the proposals of Lohrberg and Timpe [9] to see urban agriculture as a generic term that would be superordinate to urban gardening. Nor does the author here open the debate on how the same activities should be denominated when they happen to emerge in rural areas. Instead, the author proposes to look at those more traditional forms of gardening: the allotment gardens.

\section{German Allotment Gardens}

Very often, a gnome acts as the brand mark of these kinds of gardening activities in Germany. German allotment gardens seem to have a special reputation in the world: in the television documentary Deutschland Saga created by Cambridge historian Christopher Clark and broadcast in autumn 2015, he discussed typical German characteristics. One of them was the German allotment garden. He describes it as the small, fenced freedom of the Germans where everything is in good order-even the gardens.

As Appel et al. [10] quote, as early as 1909 a French journalist, Jules Huret, described this phenomenon. "After a never ending ride through flat, monotonous, stodgy, and unfertile swathes of land, through woods of fir trees, fields of mangel-wurzel and potatoes, approaching from north, south, west or east to Berlin your eyes are hit by a peculiar view which I have not had in any other place than Germany. Imagine huge surfaces of land split up into rectangles of $20 \mathrm{~m}$ in length and $10-15 \mathrm{~m}$ in width. Simple wooden fences or wires separate one lot from the next. Each user constructed rough shacks on these pieces of land. The Berlin people call them bowers (Lauben)". When and why did they appear? 
Industrialization and urbanization went hand-in-hand with higher pressures on real estate markets and, thus, with them came the disappearance or reduction of gardens and fields within the vicinity of settlement areas. The wealthier share of the population could always afford to secure their private green spaces, even on top of a better provision of public green spaces in the areas where they lived. At the beginning of the nineteenth century, however, one initiative took first steps in Germany to provide poorer social strata with land for subsistence production. As Karge [4] details, the cities Kappeln a.d. Schlei, Kiel, Berlin, and Leipzig were the forerunners of this development.

With continuing processes of urbanization, these possibilities for subsistence production near cities underwent expulsion by middle-class strata. At approximately the same time, new social objectives emerged. The poor continued to be the focus but special concern began to emerge for the children's well-being. Today, Germans use the family name of the physician Daniel Gottlob Moritz Schreber (1808-1861) as a synonym for the allotment gardens that came into being with these social activities. In the midnineteenth century, gardens furnished with bowers represented a very similar form of garden also intended for subsistence production and leisure purposes. Bundles of these lots were called bower colonies (Laubenkolonien), as continues to be the case today. The tenants obtained the nickname Laubenpieper. Most likely, this derived from ornithological nomenclature: the pipit that flourished in the bower. Thus one term relates to a person who initiated a movement, the second relates to a certain element of the facilities, and a third one-Kleingarten (literally translated: small garden)-relates to the size of such gardens. The latter is that used in the corresponding law: Bundeskleingartengesetz (BKleingG; see below). Colloquially, people use these terms synonymously.

The establishment of workers' gardens around 1900 was fostered by the beginnings of the naturopathy movement and coincided with poor living conditions in more and more of the growing agglomerations and the need for quality food. It was in 1921 when a unified association of allotment gardens in the German Reich was established throughout the country. A legislative basis was developed even earlier, in 1919 (Kleingarten-, Kleinpachtlandordnung = small land tenancy order or allotment garden legislation, translation by author). After both World War I and World War II, these garden areas were of enormous value with regard to providing accommodation for refugees and bombed-out people as well as providing food. This led to them becoming an integral part of the urban organization of land holdings and regulations in this respect. In the years or decades following World War II these plots lost some of their significance or were changed to serve other objectives: from nutrition production to more of a leisure orientation. However, we have to be aware that the allotment garden legislation [11] strictly defines the character of the land, stipulating a tenancy organization, the maximum size of garden and bower, strictly non-commercial use with non-permanent housing, and a compound arrangement of garden units administered by associations. Each of these associations establishes their own regulations. Most of them have clear rules with regard to the share of productive and non-productive square metres. Some have already adapted to the demographic changes of today and to an increase in tenants of foreign origin. For instance, on the website of the county of the Hanover Allotment Gardener's Association the regulations are available in three languages: German, Russian, and Turkish [12] (See detailed historical overview: [10]).

Figure 2 shows essential periods of development over time. The changes started slowly but steadily after World War II, and since the 1980s the allotment gardens have increasingly served leisure purposes. Furthermore, while on one hand the legal basis of allotment gardens guaranteed their long-term existence, on the other hand, the legislation led inevitably to a certain amount of bureaucracy and, not least of all, to a decrease of the attractiveness of these gardens for younger generations. Their disrepute increased as they became associated with middle-class narrow-mindedness. This ushered in a phase of the abandonment of allotment gardens, of course influenced by various other developments like changing lifestyles and demographic changes that led to abandonment because of issues related to aging. According to Appel et al. [10], the average age of the gardeners has increased over recent decades up to about sixty years which together with the bureaucratic aspects, might explain why younger people look for 'younger' forms of gardening activities. Nowadays, young families are again knocking at the doors of the allotment garden associations. They appreciate the gardens as part of their personal work-life balance. Appel et al. [10] describe in detail the presumed consequences of demographic change for consumer demand in relation to allotment garden infrastructure in different cities in Germany and their respective status quo.

For a long time already, the allotment gardens have been stable elements in the urban fabric - not only in Berlin. Although new forms of gardening are making their way in changing societies, Gröning [13] who has been working on allotment gardens since the early seventies of the last century, seemed convinced (at least in 2005), that they will continue to exist in the future despite changing needs and demands. 


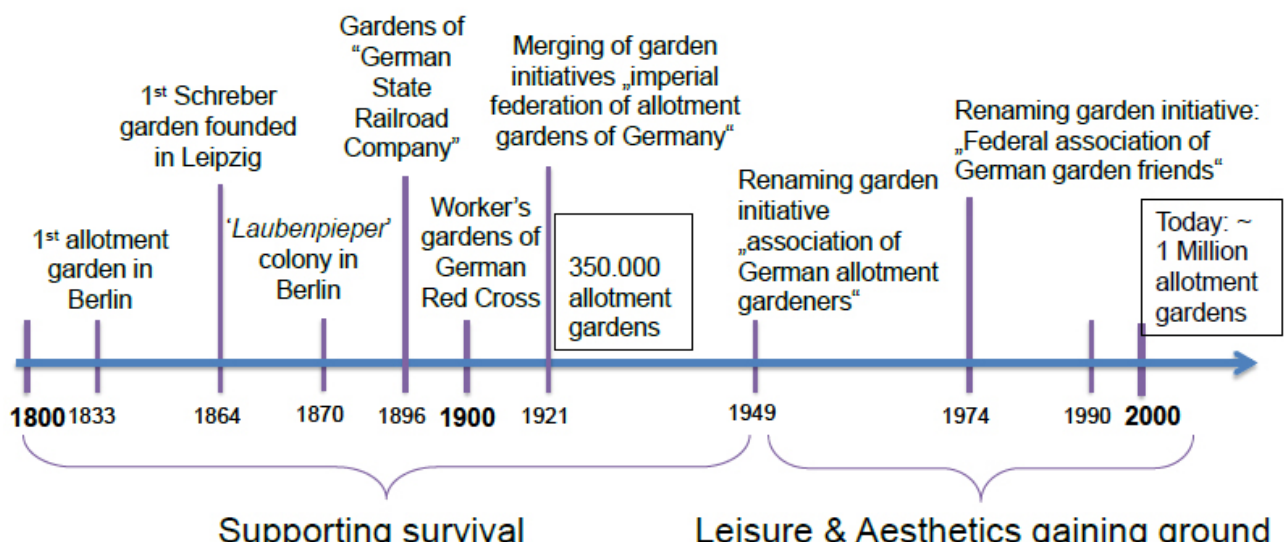

Figure 2. A timeline of allotment gardens.

\section{Urban Gardens-Contemporary New Types}

Always and everywhere new generations have wanted to satisfy their needs and express themselves with new activities in new spaces. Gardening and the shape of gardens are always reflections of the society of a given era. Thus, the emergence of contemporary new types of activities and gardens reflects social and economic developments or changes.

What are the differences between new forms of garden activities and allotment gardens? The allotment garden legislation ensures a very elementary difference: the denomination and consideration of such spaces in town planning instruments. Preparatory land-use plans and, particularly, binding land-use plans (see overview on the German planning system on the website of the COMMINproject [14]) assure the existence of most of the allotment garden areas in a fashion that does not yet exist for the majority of new forms of gardening. For the time being, the latter are in most cases simply based on temporary safeguarding. More or less, they are temporary or interim uses that may have very positive impacts on the urban area, but the people engaged in such projects face enormous uncertainty and in the end receive very little appreciation for their activities [10]. There is no evidence on whether the users of allotment gardens expect to receive appreciation in the same way, or, indeed, whether they already receive more or less appreciation for their activities.

The differences between allotment gardens and contemporary forms of urban gardening become very clear when comparing the pictures of a typical Kleingarten and a typical contemporary new type of urban gardening project (Figure 3)

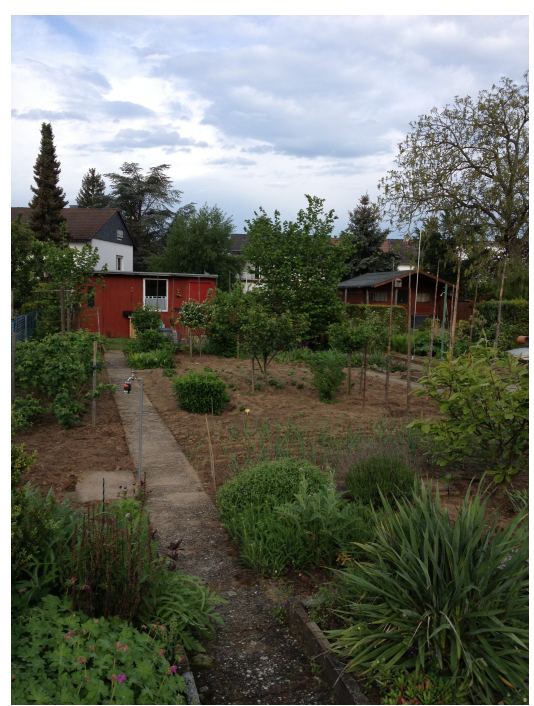

(a)

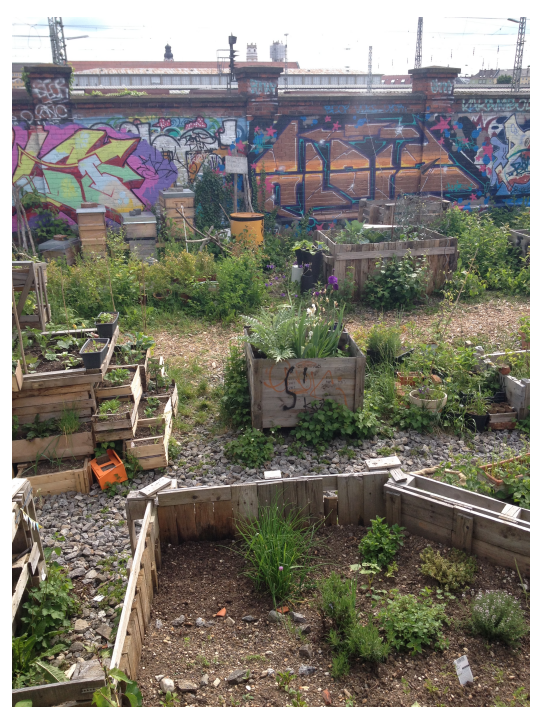

(b)

Figure 3. (a) Typical Kleingarten in the Federal State of Hessen (photography by Evelyn Gustedt). (b) Typical contemporary urban garden in the Federal State of Bavaria (photography by Anne Ritzinger). 
Looking more closely into the various types of urban gardens, we observe that both the notion of subsistence and the satisfaction of leisure exigencies are the main motivations to take part in gardening activities. Although these factors play a role, the improvement of the aesthetic and natural shape of urban areas, the enrichment of quality of life, and the shaping of new communities form a complex of motivational aspects. This goes along with awareness-raising objectives, societal learning, and the co-creation of knowledge. Some initiatives offer workshops and cultural programmes apart from gardening activities (see [1]). Certainly, one can assume that the development of civilization in general, involving fundamental economic, social, and ecological changes in ways of life in recent decades induces mental attitudes different to those held by former generations. The author hypothesizes that modern means of communication applied worldwide foster the exchange of such attitudes enormously and spread related ideas quickly. Figure 4 shows how fast this movement has developed in Germany. This growth is impressive, but the quantitative relation of urban gardens to allotment gardens is just $1: \sim 2,218$.

Various colleagues and institutions have investigated these new forms of gardening activities over approximately the last ten years. As Figure 4 shows, a certain boost in the establishment and registration of such areas took place during the last five years. If we look at the research results of Appel et al. [10], anstiftung.de [15], and spatial.ext.zalf.de [16] as displayed on their respective websites with their ongoing changes (see references), it becomes clear that the hot spots of this movement are first and foremost in Berlin, Munich, the Rhine-Ruhr-Area, the Frankfurt agglomeration, and Hamburg. The ZALF website records the registration of 79 urban garden initiatives in Berlin in February 2016. In late September 2015, the same map contained only 68 such initiatives in Berlin. The hot spots are all characterized by internationality, a high degree of urbanization, locations of higher education to an important extent, and, most likely, a high potential for innovative capacities-"the young urban avant-garde reacts to global challenges" as Christa Müller expresses on the occasion of an interview. This was published on the website of Stiftungsgemeinschaft anstiftung \& ertomis of which Christa Müller herself is managing director. She answers questions regarding definitions, coming into existence, trends and political aspects of urban gardening [17].

These contemporary forms of gardening break new ground, probably comparable to the development of squatting activities in the early nineteen eighties. Active people working on related initiatives see themselves as part of an innovative civil society of a city or city region. They wish to foster community work and to perform something meaningful and ecologically worthwhile. As Karge [4] states, urban gardening is regarded as being something Utopian, working for global equity, living in compliance with nature, safeguarding cultural techniques, and belonging to a greater global movement. A higher proportion of younger people does not wish to be separated from each other with fences, hedges and walls, although each may have a box or a container of his/her own to grow vegetables or flowers. They appropriate spaces that, very often, either private owners or the local authorities neglected.

In the majority of German cities, the departments of urban planning or urban green spaces or similar nomenclatures are responsible for the public spaces although, in most cases, a multitude of actors is necessary to realize new garden projects as Sondermann [18] demonstrates. The authorities responsible do not always appreciate voluntary initiatives to improve or up-keep neglected or derelict spaces. Sometimes the authorities would appear to face limitations caused by a lack of adopted regulation and a legislative situation that urges them to prosecute regulatory offences even where this makes no sense or even turns out to be unnecessarily negative. A young landscape architect in a northern German middle-sized city encountered the power of the authorities when she used her own financial means to give a new shape a new design, to neglected containers of washed-out concrete that dated back to the nineteen eighties. The municipality itself had originally provided the containers to refurbish a pedestrian walkway with flowers and small shrubs. With past cuts in the public budget, the municipality had long before stopped maintaining the containers but had not removed them. People had used the containers for some time as rubbish bins or dog litter boxes. The young landscape architect received a fine for unlawful appropriation. Should we therefore not think about carefully removing the dust from regulations wherever this has not yet happened? 
Testing new lifestyles and societal models

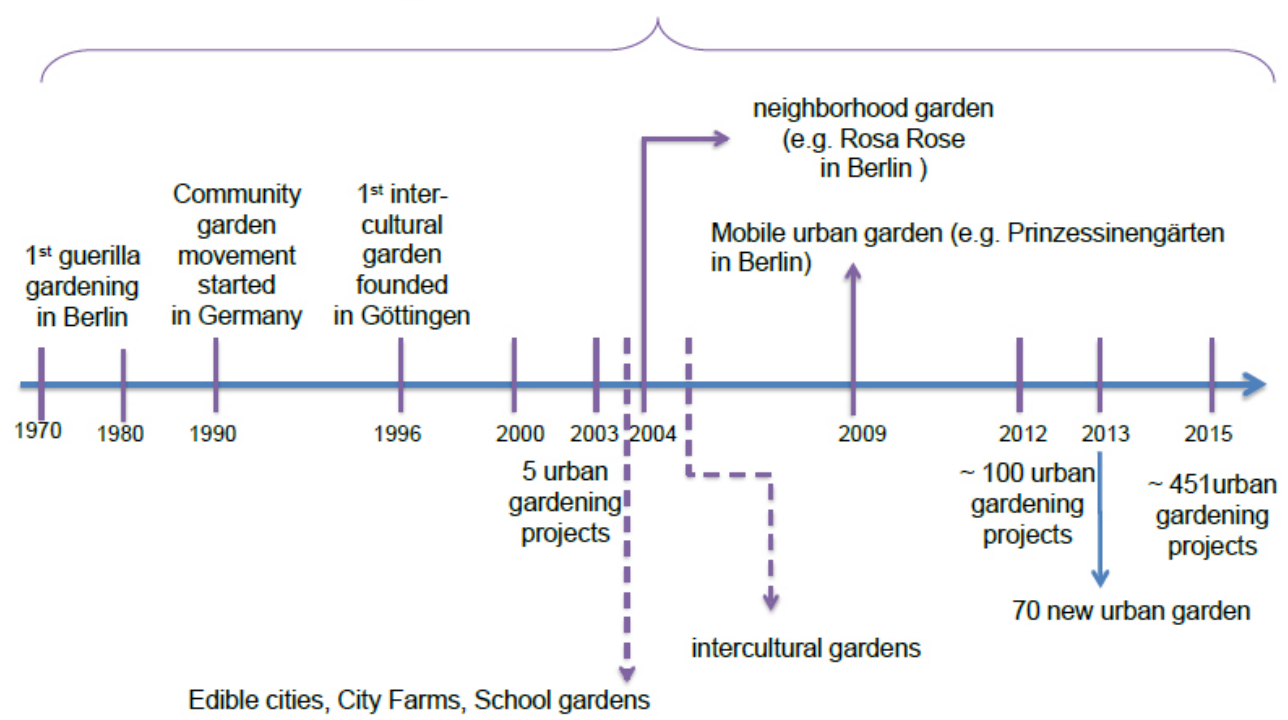

Figure 4. Testing new lifestyles and societal models—A timeline of urban gardens' development.

\section{Summarized Sustainability Aspects}

With every seedbed maintained or newly installed, a piece of nature stays or returns to town. The gardens are experimental laboratories for society. At the same time, they make people experience nature and the production of healthy food. Although the author does not join in arguments that suggest this production will ever represent a substantial share in the world's food production, the gardens nevertheless have their place with respect to social and ecological aspects of sustainability.

With regard to ecological values, one can certainly not deny that both types of gardens are to some extent stepping stones in the biodiversity patterns of a settlement area. Whether they have a high value in this respect or whether they are less important is a question that one can only answer for each specific space in relation to the surrounding situation and the city's biodiversity facilities as a whole. The same applies to the question of whether the gardens contribute to better micro-climatic conditions. Whether the food produced in allotment or contemporary urban gardens is healthier than purchased food depends on at least three variables. Where do people normally buy their food and how much are they willing to spend on it? How do they carry out the work of production in the sense of: Do they use chemical fertilizers and pesticides? One can assume that-given the general values behind the activities - the actors in contemporary urban gardens do not use these aids, although this is not to claim that those in allotment gardens do so intensively. Other questions are whether the gardens were established on derelict and therefore sometimes contaminated land or whether motorways or similar polluting elements in their direct neighbourhood exert heavy impacts on these areas.

Economically considered, the aspect of subsistence plays a certain role. However, some evidence exists (see [10]) that the individual gardeners do not really earn any significant money out of their gardening activities. The contrary seems to be more likely. Many contemporary urban gardens quite often seek subsidies from official bodies. We can presume that the municipalities, on their part, do not really gain in terms of hard revenue. However, one can argue that someone other than paid municipal staff takes care of derelict land and undertakes the necessary work to embellish such spaces or upgrade natural values. The municipalities may gain, at least, with regard to non-material goods. Such achievements might improve the reputation of a city. The engagement of citizens and their voluntary work in publicly accessible spaces goes hand-in-hand with certain municipal efforts that lead to an upgrading of the affected areas. The author argues that these effects will increase as more co-operation exists between both spheres.

The idealistic values behind the urban garden movement entail elements of post-Fordistic thinking, of critical growth theories, or new prosperity models. We can thus expect that the activities will have repercussions on society, first presumably on the avant-garde itself and on the direct social neighbourhood, namely encouraging a greater sense of identification with the local area, more social control, and the stabilization of the affected parts of society. If the processes continue successfully, the development may result in gentrification effects. This would require community intervention in other parts of the city (See [10]).

In any case, both types of gardens, allotment as well as contemporary urban gardens are an expression of social development. They both play their role and have their own value. It seems clear that they will continue to develop further and to have an impact on urban structures. It makes sense to safeguard these spaces for the sake of a liveable city. 


\section{References and Notes}

[1] Reset.org; 2016. Available from: https://reset.org/knowledge/urbangardening-mit-gaerten-die-welt-veraendern.

[2] Berges R, Opitz I, Piorr A, Krikser T, Lange A, Bruszewska K, et al. Urbane Landwirtschaft-Innovationsfelder für die Nachhaltige Stadt. Müncheberg, Germany: Leibniz-Zentrum für Agrarlandschaftsforschung (ZALF); 2014.

[3] Karge T. Neue urbane Landwirtschaft [MSc Thesis]. Berlin, Germany; 2015. Available from: http://dx.doi.org/10.14279/depositonce-4913.

[4] Karge T. Neue Urbane Landwirtschaft: Eine theoretische Verortung und Akteursanalyse der Initiative Himmelbeet im Berliner Wedding. vol. 79. TU Berlin University Press; 2016.

[5] Urbane Landwirtschaft: Was ist das? Available from: http: //speiseraeume.de/faq-urbane-landwirtschaft/.

[6] Rosol M. Gemeinschaftsgarten in Berlin: eine qualitative Untersuchung zu Potenzialen und Risiken burgerschaftlichen Engagements im Grunflachenbereich vor dem Hintergrund des Wandels von Staat und Planung [PhD Thesis]. Berlin, Germany; 2006.

[7] Sondermann M, Steffenhagen P. Urbane Gärten in der integrierten Stadtentwicklung. Gartenkunst Die Gestaltung der Natur Forschungsmagazin der Leibniz Universität Hannover. 2013;pp. 40-46.

[8] Bell S, Fox-Kämper R, Keshavarz N, Benson M, Caputo S, Noori S, et al. Urban Allotment Gardens in Europe. Routledge; 2016.

[9] Lohrberg F, Timpe A. Urbane Agrikultur-Neue Formen der Primärproduktion in der Stadt. PLANERIN Fachzeitschrift für Stadt-, Regional und Landesplanung. 2011;5:35-37.
[10] Appel I, Grebe C, Spitthöver M. Aktuelle Garteninitiativen: Kleingärten und neue Gärten in deutschen Großstädten. Kassel University Press; 2011. Available from: http://www.uni-kassel.de/upress/ online/frei/978-3-86219-114-7.volltext.frei.pdf.

[11] Legislation on allotment gardens; 1983. Available from: https: //www.gesetze-im-internet.de/bkleingg/BJNR002100983.html.

[12] Bezirksverband Hannover der Kleingärtner; 2016. Available from: www.bezirksverbandhannover.jimdo.com./links/.

[13] Groening G. Aspects of garden culture and open space development in Germany. GEOUSP: Espaço e Tempo (Online). 2005;18:201-212. Available from: http://www.revistas.usp.br/geousp/article/view/73983/ 77642.

[14] Pahl-Weber E, Henckel D, Klinge W, Lau P, Schwarm DZ, Rütenik $B$, et al. Local Land-Use Planning. In: The Planning System in the Federal Republic of Germany. BSR INTERREG III B project; 2016. pp. 49-54. Available from: http://commin.org/upload/Germany/ DE_Planning_System_Engl.pdf.

[15] Anstiftung. Die urbanen Gemeinschaftsgärten im Überblick. Available from: http://anstiftung.de/urbane-gaerten/gaerten-im-ueberblick.

[16] Location of urban gardens in Germany. Available from: http://spatial.ext.zalf.de/spatial/google_show_points_stadtacker/ default.aspx?show=all\&ct=fp.

[17] Urban Gardening. Authoreninterview: Christa Müller. Available from: http://www.urban-gardening.eu/autoreninterview/.

[18] Sondermann M, Fürst D. Zivilgesellschaftliches Engagement und die kulturelle Dimension kooperativer Stadtgrünentwicklung am Beispiel Hannovers. Neues Archiv für Niedersachsen. 2015;1:98-111. 